\title{
The relationship development aspect of production transfer
}

\author{
Lise Aaboen and Anna Fredriksson
}

\section{Linköping University Post Print}

\section{Tweet}

N.B.: When citing this work, cite the original article.

Original Publication:

Lise Aaboen and Anna Fredriksson, The relationship development aspect of production transfer, 2015, Journal of Purchasing and Supply Management.

http://dx.doi.org/10.1016/j.pursup.2015.08.001

Copyright: Elsevier

http://www.elsevier.com/

Postprint available at: Linköping University Electronic Press

http://urn.kb.se/resolve?urn=urn:nbn:se:liu:diva-121656 


\title{
The relationship development aspect of production transfer
}

\begin{abstract}
Production transfers are a result of outsourcing and offshoring decisions. Because of the strategic focus of the outsourcing literature, the operational issues of relationship development between sender and receiver and its impact on the transfer progress have not been fully depicted. The purpose of the present paper is to explore relationship development during production transfer. To fulfil this purpose, we studied three different production transfers and derived four propositions for further testing. Our main conclusions included that dependence and power gradually shift between the sender and the receiver and that the relationship between them sets the arena for what types of relationships can be developed between the receiver and the suppliers. Furthermore, short social distances can bridge cultural and technological distances to some extent, because it motivates the actors to bring their relationship into a more developed state. Finally, we noticed that the headquarters' involvement can work both as an inhibitor as well as a converter.
\end{abstract}

Keywords: Outsourcing; offshoring; production transfer; relationship development; distances

\section{Introduction}

The business environment grows less stable, and the ability of production networks to adapt to changes in the environment is becoming increasingly important (Christopher, 2010). Galbraith (1990) points to technology transfers, replications, and production relocations as strategic abilities that can help networks to achieve such adaptations. Production relocations such as outsourcing and offshoring involve carrying out production transfer, i.e., the actual physical relocation of the production of products or components between two production facilities. Production transfer is difficult because of the existing interdependency between processes at the operational level of the units (Boulaksil and Fransoo, 2010; Rehme et al., 2013; Jensen et al., 2013). A production transfer can essentially be divided into three major phases: 1) preparations before the transfer, 2) physical transfer of equipment (if applicable), and 3) production start-up at the new location (Madsen, 2009). The production transfer can also be seen as an organisational reconfiguration. Where phase 1 implies a disintegration at the original location (the sender), phase 2 is the relocation from sender to receiver (the new location) and phase 3 implies a reintegration between the sending and receiving units (Jensen et al., 2013). Because of the organisational reconfiguration following the physical transfer and start-up, a production transfer is not only a question of relocating hardware, such as equipment, systems, or facilities. To utilise effectively the transferred hardware, the new location must also receive knowledge, explicit as well as tacit (Cheng et al., 2010; Salomon and Martin, 2008; McBeath and Ball, 2012). Furthermore, according to Fredriksson and Wänström (2014) a production transfer can be seen as consisting of four parts: physical, knowledge, administrative and supply chain. All these four parts need to be reintegrated before the transfer can be seen as completed. The supply chain part of the production transfer implies that new supply chains of raw material and components to be used in the production process are created (Fredriksson et al., 2014). New supply chains are in almost all cases afflicted with uncertainties regarding yield, process reliability and lead-times (Lee, 2002). 
The suppliers in the new supply chain can be existing suppliers of the sending unit as well as new suppliers for the receiving unit specific of the transferred products or production processes. Even though a supplier can be part of both the old and the new supply chain, it is impossible to transfer a relationship from one actor to another (Andersson et al., 2001). When an existing supplier of the sender is to be used by the receiver, it follows upon the production transfer that the relationship between the supplier and the sending unit is ending and that a new relationship between the supplier and the receiving unit is beginning. A relationship can therefore not be regarded as part of the production transfer to the receiving party even though Martin et al. (1995) argue that the likelihood of being able to re-create a supplier relationship in a new location increases if the supplier relationship in the home country was long-term, i.e. the transfer of an existing supply chain. As transfer of relationships is not possible, it is necessary to establish new relationships to accomplish the supply chain part of the production transfer and therefore we need to include development of relationships as part of the production transfer process.

The initiation of the new relationship between the receiving unit and the supplier used by the sending unit (or a new supplier replacing the previous) is a temporal problem that needs to be passed as quickly as possible to decrease the uncertainties regarding yield, process reliability and lead-times of the new supply chain. It is believed that the initiation and ending processes involving the suppliers is very much connected to the relationship between the sending and receiving unit. Previous studies have reported that the sending unit sometimes do not trust the receiving unit initially. The responsibility for supply issues is then commonly kept within the sending unit and thereafter slowly transferred, step-by-step, to the receiving unit as the relationship develops (Fredriksson et al., 2014). Thus, the supplier has two customers during this time. Relationships can cause complex situations during production transfer and there are indications of that the production transfer progress is related to the relationship development (Fredriksson et al., 2014, Rehme et al., 2013). Baraldi et al. (2014) explain that the relational nature of outsourcing and offshoring is stressed in the business network literature where outsourcing decisions implies the building of a relationship with the receiver. In the business network literature the outsourcing decision also implies that activity links are changed with and between the actors and that the organizational boundaries between the actors become blurred. Baraldi et al. (2014) argue that even though there is a relational focus in the business network literature most previous studies tend to focus on the sender as an orchestrator of outsourcing relationships rather than the receiver or the relationship between them. However, explained in the previous paragraphs the production transfer includes not only the relationship between the sender and receiver but also the relationships with suppliers that the sender needs to end and the receiver needs to initiate.

The issue of relationships during production transfer has traditionally not been the focus of outsourcing/offshoring literature. Previous studies (e.g. Wasner, 1999; Boulaksil and Fransoo, 2010; Fredriksson et al., 2014) acknowledge the interdependency between the sending and receiving unit as neglected within this area. In contrast, outsourcing/offshoring literature (e.g. McIvor, 2000, Franceschini et al., 2003, Greaver, 1999, Schniederjans and Zuckweiler, 2004) focuses on the strategic aspects of outsourcing/offshoring, such as identifying the core competencies of the sender, identifying possible relationships with receivers, and deciding on the governance structure of the relationship. Recent outsourcing literature covering supply chain issues (e.g., Arlbjørn and Mikkelsen, 2014; Eltantawy and Giunipero, 2013; Najafi et al., 2014) has dealt with strategic questions of supplier-receiver relationships such as whether to substitute suppliers that are within the proximity of the sender with suppliers within the proximity of the receiver (Baraldi et al., 2014; Kamann and 
van Nieulande, 2010; Trent and Monczka, 2003). It is important to note that outsourcing/offshoring literature focusing on strategic aspects takes for granted that the relationships between the involved parties follows the production transfer progress.

There is a fair amount of literature on transfer and replication within the knowledge management area (e.g. Jensen and Szulanski, 2004; Jonsson and Foss, 2011; Rivkin, 2001). One could argue that the transfer of relationships should be part of the transfer of tacit knowledge, which would make the use of literature about templates for the knowledge transfer very fruitful. However, relationships are not a question of knowledge of how to deal with suppliers and other actors. In contrast, it is about inter-personal relationships that cannot be transferred in an unchanged state but have to be rebuilt after transfer. Even though knowledge transfer literature provides many interesting aspects, the focus of this literature stream is on the process by which one unit (e.g., group, department, division, or company) is affected by the experience of another. We also agree with Argote et al. (2003) that production transfers occur in a specific knowledge management context which may moderate the relationship between the transfer and its outcomes. The knowledge management context can be described as comprising three aspects, i.e., the properties of: (1) the two units between which an activity is transferred, (2) the inter-unit relationships, and (3) the transferred knowledge (Argote et al., 2003). Even though the inter-unit relationship is a part of the knowledge management context, the knowledge management literature to our knowledge does not focus on how this relationship impact on other relationships of the supply chain.

These other relationships are vital in order to accomplish a working supply chain that can support the transferred production with material necessary to produce. The link between the development of the focal relationship and these other relationships is the aim of this study and therefore our theoretical framework focus on relationship development, relationship initiation, relationship ending, and connected relationships. As explained above, production transfer causes complex situations on the operational level that may not develop at the same speed as the managers had envisioned during the strategic decision making. To manage production transfer better, and to fill an important gap in the outsourcing/offshoring literature, one must understand how the different relationships among the sender, receiver, and suppliers during production transfers develop over time and how the development in these relationships influences the production transfer progress.

The purpose of the present paper is to explore relationship development during production transfer.

In order to fulfil this purpose, we study three production transfers using business network literature. These production transfers differ in regards to different offshoring business models and represent either offshore outsourcing or captive shared offshoring (captive offshoring) (Jahns et al., 2006). The production transfers were from Sweden to China (offshore outsourcing), Sweden to Romania (captive offshoring), and Sweden to Hungary (captive offshoring). The Chinese receiver is an established independent company, the Romanian receiver is a new company within the same corporation as the sender (i.e. Greenfield) and the Hungarian receiver is an established company within the same corporation as the sender. This spectrum of difference in the receivers, and consequently starting point of the relationship between sender and receiver is chosen on purpose in order to provide an exploration that takes different potential situations into account. Based on the discussion by Jahns et al. (2006) we suspect that the relationship development may differ between offshore outsourcing and captive offshoring since the starting point for the development processes is different. 
During offshore outsourcing the actors are independent of each other. During captive offshoring in contrast, the receiving unit is part of the same corporation as the sending unit (Jahns et al., 2006). The two units will then, at least on paper and structurally, have a relationship with each other at the starting point of the production transfer. However depending on if the receiver is a "Greenfield" or not the independence level will vary. Given that production transfers take place in the context of a network, relationship developments will also affect other relationships in the network; nevertheless, we include only the suppliers and the other actors that were mentioned during the interviews in order to remain relevant to the focal relationships in our cases.

The structure of the paper is as follows. Section two will present the theoretical framework. Section three explains how the data were collected from the three production transfers and elaborate on the theoretical framework. Section four makes a short presentation of the three production transfers. In Section five we provide a within case analysis using our theoretical framework and a cross case analysis leading to four propositions. Finally, conclusions, implications, and suggestions for future research are provided.

\section{Theoretical framework}

According to Slotte-Kock and Coviello (2009), the analysis of how and why relationships change over time taking both actors in the relationship into account is a particular characteristic of business network research. In these analyses it is assumed that relationships are continually established, maintained, developed and broken, and the focus is on how relationships change as well as on why change occurs. Social networks are often the grounding for building new business relationships (Aarikka-Stenroos, 2008). However, business and social relationships are not the same. Business relationships are between two connected counterparts that interact and perform interdependent activities. They are often long-term relationships focused on manufacturing and technological developments through coordination and combinations of resources and activities between the two counterparts. In order to capture the whole nature of a business relationship several different interaction levels need to be analysed. Holmlund (2004) identifies five aggregation levels of interaction: action, episode, sequence, relationship, and partner base. Action is the lowest level and consists of the individual initiatives of the firms. When several actions are interconnected these groups of action form an episode, the next level of aggregation. According to Holmlund (2004) an episode can e.g. consist of a negotiation process or a shipment process. Interrelated episodes form a sequence. The sequence level of analysis can be used for all kinds of interactions in a certain project. When all sequences related to the same counterpart are grouped together we reach the relationship level of analysis. All relationships that a firm has at a particular time as a group is the partner base of that firm. Partner base is the highest level of analysis and is sometimes referred to as the relationship portfolio.

\subsection{Relationship development}

Relationships develop through stages or states. According to the stage theory, the development takes place through a movement of consecutive stages that are seen as unfolding naturally. The stage models include both life cycle models, which are programmed and often include stages that resemble the life cycle of organisms, and growth-stages models, consisting of incremental and irreversible stages (Batonda and Perry, 2003). Ford (1980) is an early proponent of the stage model, which consists of the pre-relationship stage, the early stage, the development stage, the long-term stage, and the final stage. Two important assumptions of the stage model are that the relationship consists of two active parties that interact in episodes where adaptions take place and that these adaptations lead to increased commitment. During 
the different stages, the distances between the parties become smaller when experience with each other increases and uncertainty decreases. The distances can be described from five perspectives: social distance, cultural distance, technological distance, time distance, and geographical distance (Ford, 1984). Geographical distance is the physical distance between the locations of the two actors in the relationship. One way to decrease the geographical distance is to set up a subsidiary or an office closer to the other actor. Captive offshoring may therefore be a way to decrease the geographical distance compared to offshore outsourcing. Time distance is the distance in time between for example the placement of an order and the actual delivery of the order. The longer time it is left until you know if the other party will actually do what is promised the larger the time distance. Initially the time distance is decreased by negotiations of contracts and terms, i.e. increased control. Time distance is also decreased through commitment and trust. Technological distance is the difference between the two actors' technologies. Both product technology and process technology is included here and it is decreased when the actors get to know each other's technologies and adapt to them. Cultural distance has to do with the differences in values and norms in the two organizations and this distance can be large also between two companies in the same country as well as within the same corporation. Lastly, social distance is decreased when the individuals in the two organizations become familiar with each other's way of working. Decreasing the social distance can also help overcoming the other distances (Ford, 1980).

Several authors criticised the stage theory for not taking into account the complexity of relationships and thus running the risk of becoming deterministic. From these criticisms, Batonda and Perry (2003) developed the states theory, which comprises relationship development as an evolution of unpredictable states. In other words, the relationship development can move between the states in any sequence or order. In the state model, there is also a possibility for the relationship development to move into a dormant state where it is inactive for a while. Polonsky et al. (2010) added a de-actualise phase to the states model. A relationship development process can enter the de-actualise phase at any point and move from the de-actualise phase to any phase. This addition enables the study of both active and inactive relationships simultaneously and emphasises the importance of previous interactions to current developments, because many new relationships may, in essence, be a reactivated older relationship.

Stage and state frameworks for studying relationship development have earlier been used in the context of supplier relationships. Baptista (2013) used a framework that focused on the adaptation processes in the interactions among long-term relationships in the Portuguese mining industry. The study identified drivers of the development of long-term relationships, such as the importance of the supplier's brand name, choice of channel strategy, and the functional reliability and degree of customisation versus standardisation. According to Biggemann (2012), the exchange of information is an important driver of relationships. Trust begins to grow upon the initial disclosure of information, because the disclosure generates a sense of obligation to reciprocate. However, this finding is only valid as long as the shared information is meaningful. Mitrega et al. (2012) conducted a quantitative study on the behaviours of networking capability and found that various network capabilities are needed to manage networking during relationship initiation, relationship development, and relationship termination. Mitrega and Zolkiewski (2012) studied the negative aspects of long-term supplier relationships in Poland and identified exit barriers, opportunity costs, higher risk of unstable supply, and worse negotiation positions. The authors argue that the driving forces of these negative aspects were to be found in the product, the buyer firm, the relationship, the network, the environment, and the seller firm. Still other factors can influence the relationship 
development both positively and negatively. For example, well-developed relationships include both a high degree of collaboration and a high degree of conflict (Vaaland and Håkansson, 2003).

\subsection{Relationship initiation}

The beginning of relationships has received relatively little attention in the business network literature. Based on their literature review and their inductive investigation of a Dutch company, Holmen et al. (2005) maintain that there are at least 11 different types of relationship beginnings, including counterparts that initiate contact, meetings at trade shows, and a mutual contact bringing two other parties into contact. Edvardsson et al. (2008) introduce a model of the seller's position during relationship initiation from the buyer's perspective, and it consists of three statuses: unrecognised, recognised, and considered, leading to business agreement. The process may move between the different statuses at any pace and in any order. The model also includes converters and inhibitors. The converters contribute to forward or backward movement, and the inhibitors cause the process to linger. Examples of converters are time, trust, and service offerings; examples of inhibitors are image, risk, and bonds (Edvardsson et al., 2008). Leek and Canning (2011) examine the role of social capital during the initiation of relationships, and find that the networking enacted by the parties was of more importance for initiating relationships than the existing social capital that the parties may have at their disposal. The enacted networking differed in terms of deliberate versus unplanned, direct versus indirect, time spent, and frequency of communication. Aarikka-Stenroos and Halinen (2007) focus on third parties as promoters of relationship initiation during the initiation process. The third actor could be a person or an organisation. An organisation can serve as a third actor due to economic exchange, while a person can serve as a third actor on behalf of an organisation or as a representative of a profession, depending on his or her social embeddedness. The connectedness between the dyad and other parties makes it possible to use experiences from one relationship in another relationship and to initiate relationships by introducing two parties to each other. These activities may be the result of intentional actions or coincidence (Aarikka-Stenroos, 2008). Aarikka-Stenroos and Halinen (2007) define twelve different roles that the third actors can have during the initiation: scouter, awareness builder, need creator, access provider, accelerator, advocate seller, match maker, trust builder, evaluation assistant, expectations builder, risk reducer, and provider of concrete evidence. The roles can be performed passively, whereby the third party allows the use of its name, reactively by answering questions as well as actively by making introductions. The "status of the third is based on its ability to offer an objective view about the potential business partner" (Aarikka-Stenroos and Halinen, 2007:4).

\subsection{Relationship ending}

Previous literature on relationship ending tends to focus on the consequences of ending the relationship and on the activities performed during the termination of the relationship. Havila and Medlin (2012) studied relationship ending in the context of business closure. Their case study was the closure of an Australian car manufacturing plant. They conclude that planning ahead of the business closure is of utmost importance. Thus, they created a conceptual model of ending-competence, which consists of four elements: previous experiences of ending, an understanding of different types of commitment, the interdependence of parties, and the coordination of timing and ending (Havila and Medlin, 2012). Alajoutsijärvi et al. (2000) suggest a matrix of exit strategies that are either direct or indirect as well as other-oriented or self-oriented. The indirect, other-oriented strategies include fading away and disguised exits, while direct, self-oriented strategies include attributional conflict and diverging state-of-the- 
relationship talk. In short, the different strategies are ways to hint at the desire to leave the relationship and to communicate the actual leaving. However, Alajoutsijärvi et al. (2000) do not reach any conclusions as to which strategy should be recommended.

As mentioned by Batonda and Perry (2003), relationships with no activities may merely be dormant, and relationships that have entered the termination state do not necessarily need to end but can move to another state. There are several reasons why an actor would want to restore a business relationship that has entered the termination state. Tähtinen and Vaaland (2006) identified a number of them in a literature review combined with interviews: lost relational investments, dissolution process costs, possible sanctions for future business, network limitations, and set-up costs. Moreover, Tähtinen et al. (2007) suggest a process model that can be used for recovering relationships. Their model consists of triggers, and the process itself can be divided into voicing, blackmail, attenuating analysis, and normalising. The model assumes that a relationship can enter the relationship ending process both from blackmail and attenuating analysis. Then, from normalising, the relationship can move to either a continued relationship or back to attenuating analysis. According to Tähtinen et al. (2007), the triggers can be company-related, relationship-related, or network-related. The triggers that are most likely to do irreparable damage to relationships are misfits between partners in terms of business logics, size, and power. In contrast, financial issues and service failures were found to be easier to repair as long as they are not permanent. Salo et al. (2009) used an adapted version of the process model on the recovery of triadic relationships, and revealed that the normalising of triadic relationships is related to the attraction, trust, and commitment among the parties. Havila and Wilkinson (2002) suggest an alternative view on recovering relationships where relationship energy should be transferred to other relationships. This means that a focal relationship can import energy from previous relationships while exporting relationship energy to subsequent relationships through social bonds. Ex-employees are mentioned as examples of carriers of relationship energy.

\section{Summary}

As presented in the introduction, a production transfer can essentially be divided into three major phases: 1) preparations before the transfer, 2) physical transfer of equipment (if applicable), and 3) production start-up at the new location (Madsen, 2009). Theoretically the initiation and early development of the relationship between the sender and receiver will have to take place during the preparations before the transfer as the organisational disintegration of the sending unit takes place (Jensen et al., 2013). This is in order to ensure that the relationship is developed enough to facilitate the relocation as well as reintegration. When the production at the receiver has started up it is theoretically assumed in the outsourcing/offshoring literature that the receiver is able to operate without the sender. It should be possible to terminate or move the relationship between sender and receiver to an inactive or dormant state. However, as explained by Batonda and Perry (2003) the relationship will not move between the different states "automatically" and the relationship may move back and forward in any direction, which will inflict on what reintegration need to take place (Jensen et al., 2013). Critical incidents, changes in distances and commitment as argued by Ford (1980) and third actors that can influence the relationship through at least 12 different roles (Aarikka-Stenroos and Halinen, 2007) are important factors in the relationship development. If it is a question of captive offshoring then the headquarters that made the strategic decision to transfer is an important third actor as initiator and mediator between the two parties. The headquarter can also continue to influence the process through strategic decision making during the whole production transfer as well as after. The suppliers are also important third actors since both sender and receiver need to make changes in their supplier 
portfolio in connection to the production transfer. The supplier may influence the focal relationship in different ways depending on if the supplier is involved in a relationship that is terminating or initiating (or both, if the supplier is to be "transferred"). We view the entire relationship between the supplier and sender/receiver as a third actor influencing the focal relationship. The theoretical framework for exploring production transfer is illustrated in Figure 1 below. Based on the above discussion of the theoretical framework, we have identified research questions that will help us explore the production transfer from a relationship development perspective. The questions are meant to be answered as a hierarchy.

-How is the relationship between the sender and receiver related to the production transfer progress?

-How do the relationship between the sender and receiver develop?

-How is the relationship between the sender and receiver related to third actors?

In the end of the method section we will elaborate on how we use the aggregation levels of relationships presented by Holmlund (2004) in order to make our analysis richer.

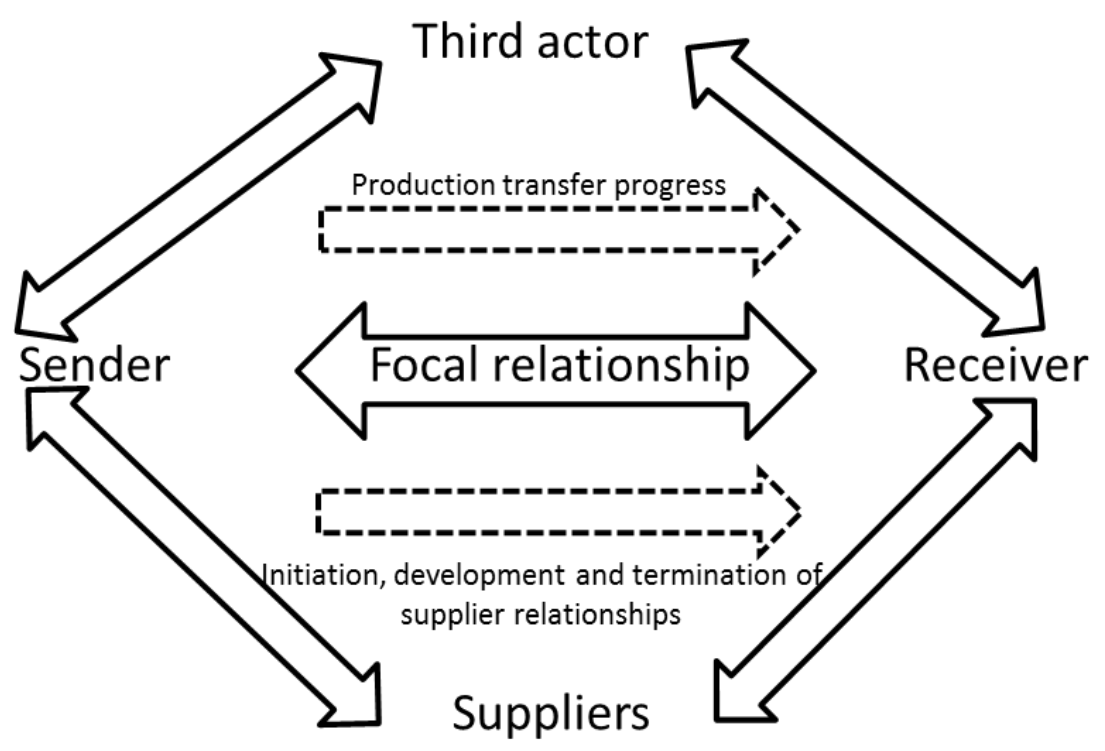

Figure 1: Theoretical framework for exploring production transfer.

\section{Research method}

The study of the production transfer process combines two important theoretical streams, supply chain management and business network literature, in order to discover why the benefits of outsourcing and offshoring decisions do not materialise automatically (Horn et al., 2013). While studying outsourcing/offshoring from an operational point of view focusing on the execution, i.e. the production transfer and start-up after transfer, Fredriksson (2011) observed that the raw material supply chain is an especially difficult obstacle. Thus a problem has been identified in the conjunction between the execution of the outsourcing/offshoring and the following development of the new supply chain, but the supply chain management literature cannot provide the full answer. Therefore, we use a theoretical framework of relationship dynamics from the business network literature to explore how the entire lifespan of relationships can help to explain why the benefits of outsourcing/offshoring decisions do not materialise automatically. 
The focus on understanding dynamics that are present within a certain kind of setting points toward case studies (Eisenhardt, 1989). Case studies is a valid choice when the context and experiences are critical to understanding the phenomenon comprehensively (Barratt, 2011). However, since we are focusing on particular aspects i.e the relationship developments, we observe this aspect in three different cases of production transfer and compare them as suggested by Flick (2015). Hence, the authors selected an exploratory multiple-case research design (Yin, 2003). Multiple-case is an appropriate research strategy when the purpose is to identify and describe critical variables, because multiple cases enable the researcher to study how different production transfers developed regarding their relationships related to materials supply responsibility and thus to identify critical variables in relation to relationship dynamics in conjunction to the transfers. In order to address the complexity of interdependencies, interconnectedness, and time, Ryan et al. (2012) recommend a process perspective and critical realist ontology. In this paper, we study three production transfers: from Sweden to China, Sweden to Romania, and Sweden to Hungary. The study object in this paper is the production transfer and the relationship development in conjunction to this with the relationship between sender and receiver as the focal relationship. Each production transfer is unique because a transfer cannot be repeated with the exact same product, or exact same sender and receiver. For each transfer the sender and receiver also gain experiences which leads to them not acting in exact same way next time. However, what have been hold constant between the studied transfers are that the transfer is going from Sweden to abroad, the perspective of the sender and that the transferred object is an industrial product to be used in assembly of a final product. Furthermore, also the scope of the transfer has been moderate in all three cases and in order to have transfers that are possible to overview the transfer has only included one product group or line. Table 1 describes the three transfers and the data collection. Power in a relationship is often linked to differences in company size but it also has to do with if one actor is dependent on the other and if one actor is able to force the other actor do things (Munksgaard et al., 2015). This means that a smaller firm may be able to compensate for their size and gain more power in the relationship than it would otherwise have had by for example technical expertise. In order to provide an overview of the power in the relationship between sender and receiver in the Power and size row of Table 1 we therefore include both the difference in size and if the actors are dependent on each other. In the Scope of the transfer row of Table 1 we separate between production line and product group. The difference between production line and product group in relation to the transfer is that in regards of a production line is the whole line mounted down, transferred and re-built in the new place and the machines are set in the same order as before the transfer. Whereas for a product group it is common that machines are replaced with existing machines at the receiver and that the layout of the shop floor looks differently after the transfer.

\begin{tabular}{|l|l|l|l|}
\hline $\begin{array}{l}\text { Number of } \\
\text { interviews }\end{array}$ & Sweden-Romania & Sweden-China & Sweden-Hungary \\
\hline Type of transfer & $\begin{array}{l}\text { Captive offshoring to } \\
\text { Greenfield receiver. }\end{array}$ & $\begin{array}{l}\text { Offshore outsourcing to } \\
\text { established receiver with } \\
\text { whom earlier relationship } \\
\text { exist. }\end{array}$ & $\begin{array}{l}\text { Captive offshoring to } \\
\text { established receiver. There } \\
\text { have been earlier interactions. }\end{array}$ \\
\hline $\begin{array}{l}\text { Reason for } \\
\text { production transfer } \\
\text { and selection of } \\
\text { receiver }\end{array}$ & $\begin{array}{l}\text { New factory in order to } \\
\text { access low cost labour. } \\
\text { Receiver selected } \\
\text { because of headquarter } \\
\text { requirement. }\end{array}$ & $\begin{array}{l}\text { Management decision to } \\
\text { outsource Chose the } \\
\text { localisation based on } \\
\text { existing relationship. }\end{array}$ & $\begin{array}{l}\text { Swedish factory shut down. } \\
\text { Receiver selected because of } \\
\text { headquarter requirement to } \\
\text { gather similar production } \\
\text { resources to a few units within } \\
\text { the production network. }\end{array}$ \\
\hline
\end{tabular}




\begin{tabular}{|c|c|c|c|}
\hline Power and size & $\begin{array}{l}\text { Sender larger and } \\
\text { relatively independent of } \\
\text { receiver. }\end{array}$ & $\begin{array}{l}\text { The Chinese receiver much } \\
\text { larger than the Swedish } \\
\text { buyer. Sender highly } \\
\text { dependent on receiver. }\end{array}$ & $\begin{array}{l}\text { About the same size, however } \\
\text { sender dependent on receiver } \\
\text { due to lack of in-house } \\
\text { knowledge. }\end{array}$ \\
\hline $\begin{array}{lll}\begin{array}{l}\text { Scope } \\
\text { transfer }\end{array} & \text { of the }\end{array}$ & One production line. & One product group. & One product group. \\
\hline $\begin{array}{l}\text { Parallel production } \\
\text { or clear cut transfer }\end{array}$ & $\begin{array}{l}\text { Parallel production } \\
\text { Life-cycle nature of } \\
\text { supplier relationships. }\end{array}$ & Clear cut. & $\begin{array}{l}\text { Parallel production } \\
\text { Life-cycle nature of supplier } \\
\text { relationships. }\end{array}$ \\
\hline $\begin{array}{l}\text { Problematic issues } \\
\text { in the production } \\
\text { transfer mentioned } \\
\text { in the interviews }\end{array}$ & $\begin{array}{l}\text { Local experience } \\
\text { missing. Need a lot of } \\
\text { support from high-cost } \\
\text { countries. Transferred } \\
\text { lines never reached the } \\
\text { same capacity as before } \\
\text { the transfer. Customers } \\
\text { worried about quality. }\end{array}$ & $\begin{array}{lr}\text { Quality } & \text { problems. } \\
\text { Communication } & \text { problems. } \\
\text { Sub-suppliers } & \text { did not } \\
\text { understand } & \text { quality } \\
\text { demands. } & \end{array}$ & $\begin{array}{l}\text { Identification and start-up of } \\
\text { sub-suppliers took longer time } \\
\text { than expected. Quality } \\
\text { problems during start-up. } \\
\text { Products too complicated for } \\
\text { some sub-suppliers. } \\
\text { Responsibilities were not } \\
\text { handed over, which caused } \\
\text { additional administration. }\end{array}$ \\
\hline
\end{tabular}

Table 1: Description of the data collection and motivation for case selection.

Since we wanted to establish how the relationship between receiver and sender related to the transfer of responsibility for materials supply, we aimed to include cases with differences in the conditions of the sender and receiver relationship so that we could compare them. Differences in the starting point of these relationships are therefore assumed to provide differences in the development of the relationships and consequently the progress of the production transfer. An important dimension in the starting point of the relationship development is how familiar the two parties are with each other. In contrast to "regular" business relationships where the parties first need to find each other the two parties in a production transfer are decided by a strategic decision. If the two parties are part of the same corporation they are more likely to be familiar with each other's way of working, by being part of the same structure, even though they may operate rather independently. If the receiver is an established firm it is more likely that the sender or another actor in the senders network is familiar with the firm compared to if the firm is newly started. The dimensions of the receiver creates a two by two matrix illustrated below (see Figure 2). As can be seen in Figure 2 we have one case from each quadrant except for the situation of a receiver that is newly started and independent. However, to our knowledge this is a situation that is rather uncommon in practice. This is also confirmed by previous research of production transfers (e.g. Madsen, 2009; Cheng et al., 2010). 


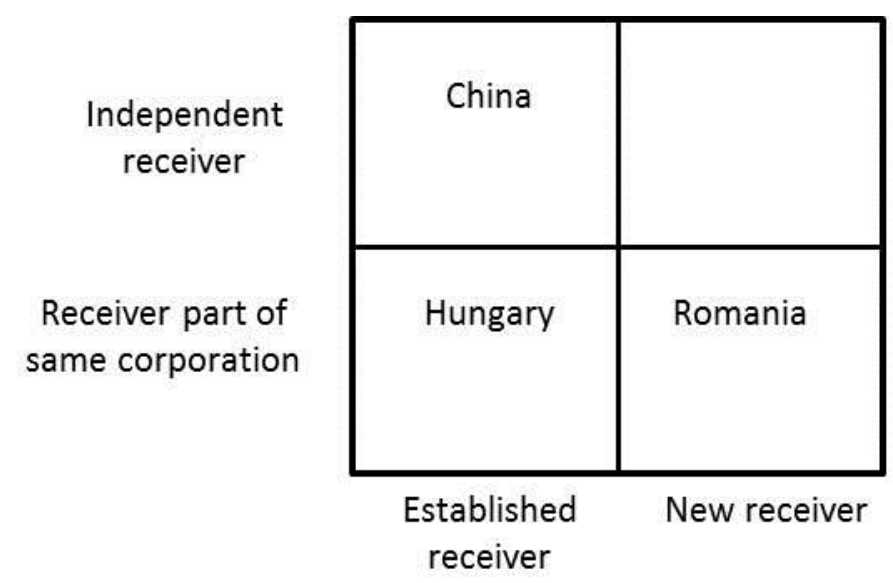

Figure 2: Selecting cases based on important dimensions connected to the receiver.

The data were collected through semi-structured interviews with the help of an interview guide, as recommended by Halvorsen (1992). After each visit, the interview notes were transcribed into an electronic case study protocol, and they were analysed through this protocol based on the themes in the interview guide (Eisenhardt, 1989, Voss et al., 2002). A total of 21 interviews were carried out at the Swedish production sites between 2009 and 2011, so the perspective of the relationship development is more Swedish than it would have been if they were carried out at the other production sites. There is then a risk that the analysis becomes built on assumptions of the parties. However, the interviews progressed more efficiently, because the interviewer and interviewee shared mother tongue as well as cultural framework. At the production sites managers and responsible within purchasing, production planning, production, logistics and transfer project leaders were interviewed regarding project plan, materials supply, supply chain management, and supply chain relationships issues. Interviewing a great range of leaders captures several aspects of the relationships as well as their developments over time. According to Holmlund (2004) interviews with only CEOs tend to generate rather general information while interviews with relationships-significant individuals of all levels tend to provide insights in the whole range of relationship aggregation levels. Notes were taken during each interview, and complementary questions were asked via telephone and email. Moreover, asking several persons the same questions validated the interview data. Finally, the respondents were given the opportunity to read the case description and to comment on it.

The analysis of connected relationships with for instance suppliers can easily become blurry since there are few clear boundaries as to what should be included. There are many ways to identify relationships. Leek and Mason (2010) argue for the benefits of utilising network pictures to capture the employees' perceptions of supplier relationships. In the present paper, however, we begin with the physical resource flows, and assume that there is a business relationship connected to each flow. These flows are the starting point for all of the interviews, even though connected relationships that were mentioned during the interviews are also included in the analysis.

In order to provide an in-depth analysis of the cases using the framework (Figure 1) presented in the theoretical framework we use the five aggregation levels of relationship presented by Holmlund (2004). In the lowest level of aggregation we focus on critical incidents among actions in the relationship developments captured in the cases. These are then grouped into episodes and combined with episodes mentioned in the cases. These episodes inform us about 
adaptations made in the relationships and changes in the distances. Among the sequences we find the relationships between the sender and its suppliers as well as the relationships between the receiver and its suppliers. From the point of view of the focal relationships the relationships with the suppliers can be viewed as interactions pertaining to a particular project and the perception of how these relationships are developing will influence the focal relationship. In the partner base we find potential third actors that may influence the development of the focal relationship. Since captive offshoring and offshore outsourcing takes place within a production network and the actors in the captive offshoring are even part of the same corporation re-activation of dormant relationships and relationship energies may be of importance. Similarly, the headquarters may be an important third actor as a decision maker and influencer. However, there will also be potential third party roles identified by Aarikka-Stenroos and Halinen (2007) that will not come into play due to the familiarity between the parties at the starting point. In the cross case analysis we will be able to compare the differences among the cases at the different levels of analysis. By switching aggregation levels we will also be able to compare how the incidents at the different levels of analysis have influenced other levels and the development of the focal relationships and the production transfer progresses as depicted in Figure 1. The principal table for aggregation levels and the corresponding data is found in Table 2 below.

\begin{tabular}{|l|l|l|}
\hline Dimensions & Level of analysis & Data from case \\
\hline Development & Partnerbase & Third actors \\
\cline { 2 - 3 } Initiation & Relationship & Movement between states \\
\cline { 2 - 3 } Ending & Sequence & Supplier relationships \\
\cline { 2 - 3 } & Episode & Changes in distances, Adaptations \\
\cline { 2 - 3 } & Action & Critical incidents \\
\hline
\end{tabular}

Table 2: Aggregation levels in during the within-case and cross-case analyses (Adapted from Holmlund, 2004).

\section{The three production transfers}

\subsection{Sweden to Romania}

Swedish Company $\mathrm{C}$ is a manufacturer of items for the automotive industry. This company is the headquarters of a large, multinational corporation. The products transferred were high tech components that are complicated to produce and contain hazardous materials. In January 2005, the corporation decided to build a new factory in Romania for two different product groups with similar manufacturing processes. One product group was made in France, and one was made in Sweden. The reason for building a factory in Romania was to get hold of low cost labour and suppliers. The corporation had earlier experience with starting up new factories and had a relatively clear idea of how they wanted the process to be. The construction work in Romania began in June 2005, and finished January 2006. When the construction work was finished, Swedish and French employees were sent to Romania to set up the organisation and to hire the Romanian employees. Swedish Company C follows a standard for transferring the production part of their product development process, and this standard takes for granted that the receiving organisation has a well-functioning and experienced manufacturing organisation. Meanwhile, several other companies were starting up factories in Romania as the same time as Swedish Company C, which decreased the company's ability to build a local knowledge base and made the factory more dependent on French and Swedish support than expected. There were also problems related to customs and achieving approvals for manufacturing, including the hazardous materials. Furthermore, it 
was very important to get customer support for the transfer, and the customers were worried about how the transfer would affect quality, which slowed down the process. In addition, the transferred lines did not work well with the on-site production organisation in Romania, so the lines never reached the yield and capacity they had before the transfer.

In general, the suppliers used by the factory in Romania were also used by Swedish Company $\mathrm{C}$ and the change had been small because of the presence of expats. Some suppliers had been changed in order to utilise the local, low cost supply, so some existing suppliers, in turn, started factories in Romania. In this particular case, four suppliers followed Swedish Company $\mathrm{C}$ to Romania and started their own factories there. One worked out well and has even hired local managers. Another was not managed well, but they had already been experiencing financial problems in France. A third went into bankruptcy after the transfer, and has been replaced by another supplier. The fourth supplier had a 10-12 year plan to establish itself in Romania, but purchasing thought this plan was too slow. The goal of finding low cost suppliers was not reached since it was their previous suppliers that moved with them to Romania and needed a lot of support from high-cost countries, which increased prices.

\subsection{Sweden to China}

Swedish Company $\mathrm{X}$ was a relatively small EMS manufacturer of mission critical communication systems. These types of systems receive information and generate measures including base stations and items. The transfer project was initiated as a response to the manufacturing management's wish to look at possible products to outsource. Purchasing visited seven possible suppliers, all in Asia. The Chinese contract manufacturer that Swedish Company $\mathrm{X}$ selected was world leading within contract manufacturing and had been a large supplier to Swedish Company X for six years. They were selected based on price and earlier experiences of good cooperation. The fact that the offshore outsourcing company was a relatively small company and it is time and resource-consuming to handle several contract manufacturers in Asia also came into play in the decision. To quote the purchasing manager, "It is better to have all problems collected in one place." The transfer project should have started in May 2009, but there were disagreements regarding contract terms, and the transfer project was restarted in August 2009. The production phase out in Sweden was set to a fixed date at the end of December 2009, and, due to the delayed project start, the transfer was rushed and left insufficient time to build necessary safety stocks. Six weeks before the end date, production began in China. After the transfer, there was a lack of components, and Swedish Company $\mathrm{X}$ helped to purchase them from sources other than the ones used by the receiving Chinese supplier, because the Chinese supplier prioritised other larger customers. The supplier was managed based on capital binding and was not allowed to buy components not reserved by the forecast. Therefore, problems with component availability arose with late changes in the production plans.

The customers of Swedish Company X did not respond positively to the transfer, and had to be convinced that the transfer would not affect quality. Therefore, all products produced in China were sent to Swedish Company X for quality control and thereafter to the customers. During start-up, it was discovered that the soldering on the circuit boards was too weak. The Chinese supplier paid the extra costs for this shortcoming. Other quality issues were discovered late in the start-up, and one explanation is the well-established relationship between Swedish Company X and the supplier. When the quality problems were revealed, 
experts were sent over. If there was no representative on location, Swedish Company X struggled to get hold of all the right information.

Swedish Company $\mathrm{X}$ has been allowed to influence who should be involved in the work on the Chinese receiver side. The Chinese receiver usually undergoes a large number of personnel changes every year, especially among the small customers, which includes Swedish Company X. The Chinese receiver chiefly uses small companies to train their newly employed personnel, and sometimes changes, in who is involved in the work, are made without notification. Swedish Company $\mathrm{X}$ has also had a third person, in form of a local representative in China. However, it has also been necessary to have Swedes in China. The communication with the Chinese supplier was sometimes problematic because of the supplier's lack of English skills. Thus, a common document handling system was important. The time difference has also been a problem. Swedish Company X has tried to start early in the mornings to get as many hours as possible together. Nevertheless, the majority of the problems have been related to materials supply to the Chinese receiver and the quality of the material from the suppliers.

The suppliers of electronic components remained (i.e. was transferred from sender to receiver), because they were global actors. A new local Chinese supplier of circuit boards was identified. The plastic caps and the packaging material were made by Swedish suppliers, but it was not economically feasible to fly these materials to China; thus, new Chinese suppliers were identified. This caused some problems, as the Chinese suppliers did not understand the demands placed on them. For example, the labels did not stick properly, since the plastic had not been cleaned sufficiently. A question after the transfer was therefore to find out what information regarding the packaging was missed. The company used a military circuit from an Israeli supplier and using this circuit in China involved export and import permissions, which took time.

\subsection{Sweden to Hungary}

Swedish Company A belonged to a worldwide corporation with headquarter in Europe. Swedish Company A developed, manufactured, and sold products for use in energy production, the oil industry, and the gas industry. The final products were assembled at Swedish Company A's main site in Sweden. The transfer concerned the production of cold and warm compressor blades, which are mounted to the final product. Before the transfer, the compressor blades were produced in a Swedish factory that was owned by Swedish Company A yet located in another city in Sweden. It was the corporations European headquarter that decided to close the Swedish factory down in order to decrease number of units within the corporation and transfer the production of cold compressor blades to a Hungarian sister company. The Hungarian sister company has the same production capacity as the Swedish factory and the same independency level as the Swedish Company A. The Swedish Company A was appointed responsible of the transfer as the Swedish factory lacked competence and because it was owned by the Swedish Company A. (The production of warm compressor blades was transferred to Swedish Company A's main site in Sweden, but the case description below will focus only on the transfer to Hungary.) The fact that Swedish Company A and the Hungarian receiver were sister companies was an issue. The European headquarters sent double messages that more volumes should be placed internally; however, at the same time, they wanted to have external competition. Other issues were that Swedish Company A was a relatively small customer to the receiver in Hungary and that the Hungarian receiver did not like external competition. 
The transfer project started in December 2003. In May 2004, the shutdown of the Swedish factory was communicated to the employees, and they were offered a stay-on bonus in order to encourage a stepwise shutdown. The original plan was to close the Swedish factory in December 2004. In September 2004, it was decided to prolong the production in the Swedish factory to April 2005, since the identification and start-up of the second sources took longer than expected. In November 2004, the ramp-up at the receiver in Hungary began. The receiver was projected to reach a steady state in six months, but it took about fourteen months. In June 2005, the remaining parts of the Swedish factory were sold to a small, local company and remained as a supplier. There were massive quality problems during start-up in Hungary due to the products not fulfilling tolerances. The receiver in Hungary was not involved in the decision of which machines to transfer and who should do the refurbishing. The receiver in Hungary was not happy with being left out of the decision-making, and thus tried very hard to show that the machines did not work as expected. These machines were later transferred to another sister-company where they worked very well.

Before the transfer, $80 \%$ of the volume was made by the Swedish factory, whereas $20 \%$ was made by existing sub-suppliers (one British, one Italian, and one Swiss supplier). For the Swiss and Italian firms, the transfer involved merely a change in address, whereas the British supplier received increased volumes to complement the production in the Swedish factory and the Hungarian receiver, because the British supplier possessed the highest competence. When the Swedish factory was closed down, the purchasing from these three sub-suppliers was transferred to Swedish Company A. Furthermore, some new sub-suppliers were identified. Establishing contact with the suppliers and explaining the manufacturing technology had proved to be a great undertaking. In general, it can be said that the production transfer was more complex than the transfer of standard products that the Hungarian receiver and the other suppliers had earlier experience of. A portion of the production was transferred to a supplier that was not capable of doing what was expected, which had been missed by the Swedish factory. The purchasing function at Swedish Company A that was responsible for this comprised three persons: one operative, one strategic, and one key commodity buyer.

During the start-up, the Swedish factory and the receiver in Hungary have been equally important suppliers of compressor blades to Swedish Company A. Their business had enjoyed affluent times, and Swedish Company A had been able to satisfy all of the volume demands from its customers but the company plans to prioritise new suppliers in the near future. The Swedish factory is immensely important because of the knowledge it possesses and its ability to provide good service at reasonable prices, even though it cannot compete stiffly with the new suppliers. Transferring the knowledge from the Swedish factory to Swedish Company A has been difficult, which continues to make Swedish Company A dependent on the Swedish factory.

Raw materials were bought on long-term contracts. The Swedish factory had its own raw material inventory, and, until this inventory was emptied, raw material was sent from the Swedish factory to the suppliers (including the Hungarian receiver). However, there were problems with assuring that raw material would be available and moving the material out of the Swedish factory inventory, so the purchasing of raw material was transferred from the Swedish factory to Swedish Company A. When the raw material inventory at the Swedish factory was emptied, raw material was sent from the raw material supplier to a VMI warehouse in central Europe, and thereafter to the compressor blade suppliers. Forecasts were sent to the central VMI warehouse, and it ordered raw material based on them. The forecasts 
led to extra administration for Swedish Company A, because the responsibilities were not handed over. Therefore, the Hungarian receiver was essentially treated as a LEGO supplier. As a final step, the purchasing responsibility of raw material was transferred to the Hungarian receiver. In retrospect, Swedish Company A considered this failure to hand over the responsibilities one of the problems of the start-up of the Hungarian receiver as the main supplier of cold compressor blades.

\section{Analysis of supplier transfers}

In the following section, the cases of production transfer will be analysed using the theoretical framework of relationship development.

\subsection{Within case analysis}

The within case analysis will be made first for each case based on the structure presented in Table 1.

\subsubsection{Sweden to Romania}

On a relationship level the technological distance acted as an inhibitor of the advancement of relationships between both the sender and the Romanian factory as well as between the Romanian factory and the existing suppliers. The technological distance hindered the Romanian factory from taking full responsibility of the relationship with suppliers. At the sequence level the transfer could be viewed as taking place within the existing relationships (between existing suppliers and sender), though with the goal of forming new relationships between existing suppliers and the Romanian factory. On paper, the transfer appeared to be only an increased geographical distance, since expats were running the factory in Romania and the suppliers followed the transfer to Romania and started factories there. Though, the technological distance hindered the progress of the transfer according to plan and the episodes focused around overcoming the technological distances. A technological distance between the sender and the receiver as well as between the suppliers and the receiver arose in this case because the Romanian factory was a Greenfield factory lacking in developed routines, methods, and processes. The transfer plan had not accounted for this technological distance at all. Therefore the actions focused on the local management. The local management was not ready for the transfer, and Company $\mathrm{C}$ struggled to recruit suitable persons as there was a competition between several companies starting up simultaneously.

At the partnerbase level, as expected when studying a transfer to a "Greenfield" site, the headquarter was an important third actor. It had initiated the construction of the Romanian factory and the transfer with the goal to decrease costs. Thus the Romanian factory was seen as an offshore factory, i.e., responsible only for producing and for nothing else (Ferdows, 1997), which set the expectations of what responsibilities the factory should take. Tähtinen et al. (2007) argue that misfits between partners may act as triggers for relationship endings, but, in this case, the suppliers and customers chose to save the potential relationship with the Romanian factory, because this relationship was tightly linked to their relationship with the sender and the headquarter. Customers were also a third-actor in this case as these had concerns of how the transfer would affect quality, further slowing down the transfer of responsibility and keeping the view of the Romanian factory as an offshore factory.

\subsubsection{Sweden to China}


At the relationship level the transfer from Sweden to China involved an existing relationship that was intensified by adding further joint activities between sender and receiver. The relationship in this case was based on both parties' agreement and expectation that the Chinese supplier should act as a sub-supplier whose role was to produce. The relationship is therefore not a well-developed relationship as defined by Vaaland and Håkansson (2003), and it is rife with both trust and conflicts. The reason for keeping the relationship in this state was because Swedish Company X was so small in relation to the Chinese supplier that the former was afraid of not being prioritised and therefore wanted to maintain control over some aspects.

At the sequence level it can be seen that there were contract issues affecting the progress of the preparations of the transfer that spilled over on the progress of the transfer itself as the preparations had not managed to include all issues due to shortened time frame. We can see that the Swedish Company $\mathrm{X}$ is maintaining control over numerous aspects which stops the relationship between the sender and receiver from developing into a higher state. The Chinese supplier was not allowed to decide which suppliers to use or what inventory levels to have, and all of the quality control took place in Sweden. Even though this was a part of the agreement between the sender and receiver, this agreement led to some level of inherent mistrust. A clear analysis was carried out by the Swedish Company X regarding which supplier relationships to transfer or keep and where to identify new relationships and even this well-planned transfer project had to be rushed. The episodes circles around social and technological distance and the inherent lack of trust in the relationship between sender and receiver does not affect their social distance, surprisingly. As for the social distance itself, its impacts are the frequent changes in the contact person at the supplier and the parties' lack of willingness to share problems.

At the sequence level after transfer we can also see the issue of the quality problems discovered. The longstanding relationship and the triumph over technological and cultural distances has made the companies overconfident and has drawn their attention away from the increased technological distance that comes with the new transfer. Their tardy discovery of this distance caused the relationship to return to an earlier state with increased control from the Swedish side. Though, we can see that the Swedish Company $\mathrm{X}$ are taking actions to improve the relationship once again by trying to decrease the geographical distance as defined by Ford (1980) by placing a representative in China who acts as a third-party. Swedish Company $\mathrm{X}$ is also trying to bridge the geographical distance by adjusting its work hours for more direct communication, and the receiver takes action by allowing Company $\mathrm{X}$ to decide who should be its contact person. There are also critical incidents where a new Chinese supplier does not understand the Swedish company's quality demands, which further widens the technological distance. However, this lack of comprehension by the supplier is not affecting the relationship between the Chinese receiver and the Swedish Company X, because the latter has selected the suppliers.

We can see at the partnerbase level that in this traditional offshore outsourcing relationship, the third actors are the customers that show a fear of quality failures in conjunction with the transfer and the Israeli supplier that is reluctant to deliver to China. These are acting as inhibitors to the transfer.

\subsubsection{Sweden to Hungary}


At the relationship level the transfer from Sweden to Hungary, is an example of a lack of trust and a fear of dependency. The Swedish Company A has a purchasing strategy of avoiding tight relationships, so it puts extensive effort into developing relationships with other suppliers instead of focusing on the relationship with the receiver. The Hungarian receiver on the other hand feels as if it is treated as a sub-supplier, even though it had the expectancy of being seen as an independent supplier because of its experience and their sister company relation. At the sequence level we can see that the lack of trust at the relationship level inhibits the progress of the transfer. The sequence level has two foci: 1) Create a central solution for the raw material supply of steel to both the Hungarian receiver and the other suppliers in order to separate the raw material supply from the sender and to create a feeling of independency at the Hungarian receiver and 2) making the Hungarian receiver accept the machinery. Though at the episode level, the lack of trust between the Hungarian receiver and Swedish Company A creates a technological distance, which manifests as the Hungarian receiver's unwillingness to accept the Swedish machines. The receiver starts to voice its concerns about the relationship when it perceives knowledge as being withheld from it. These actions are rather obstructive, slowing down the process of developing the relationship and, in some instances, even reversing the process. Further episodes are related to that the Swedish Company A has bypassed the receiver in several decisions due to a lack of trust.

At the partnerbase level the common headquarters acts as a third party and converter in the relationship initiation in this case by initiating the transfer. However, their wish for competition, given their inclination toward internal suppliers, has prompted their selfinterested actions, the lack of trust, and the efforts of the Swedish company to identify new suppliers instead of developing the relationship with the existing suppliers. In this case we also have a third party in the Swedish Factory. The Swedish Company A have a large fear of dependency as stipulated earlier and this fear hinders them from developing a tight enough relationship with the Swedish Factory to enable knowledge transfer. However, this was counter productive as it increased the dependency of the Swedish Company A on the Swedish Factory. The absent knowledge transfer kept the technological distance to the Hungarian receiver as the knowledge needed to decrease this was not available within the Swedish Company. The Swedish Company A feels threatened by this dependency and talks about prioritising other suppliers and even taking this relationship into the termination state.

\subsection{Cross case analysis}

The cross case analysis compares the cases between the different levels of analysis from Table 1. Figure 3 is developed from Figure 1 based on the cross case analysis. The analysis is summarized in four research propositions for further research.

Havila and Wilkinson (2002) observed that relationship energy can be transferred between relationships. Therefore our case studies' previous sender-receiver sequences of interactions should be of importance. In the cases we can see that the episodes within the sequences taking part before and during the transfer affect the relationship development because of how these have affected the distances between sender and receiver. In the transfer between Sweden and Hungary, the social distance was large due to their previous sequences of interactions, which generated a lack of trust and a lengthy process. The Sweden-to-China transfer shows an example of when the two actors perceived the social distance to be small and therefore expected the transfer to be easy. The parties therefore overlooked many issues and lacked foresight. Thus we see that the previous sequences of interactions if they have led to small social distance can decrease the impact of smaller problems during transfer. In the 
Sweden-to-Romania transfer on the other hand, there were no previous interactions, with the Romanian factory being established due to the transfer. It was therefore possible to evolve the relationship in any direction. At the same time, lack of previous bonds prevented the relationship from developing quickly. Another point that is visible in the analysis in relation to social distance is that social distance and technological distance seem to be the two distances that hinder relationship development the most during production transfer. The technological distance could be decreased or increased by actions in the relationship between the two factories. We can see that lack of trust because of social and technical distance hindered further developments of relationships between receiver and supplier in all three cases. Thus the relationship between the sender and the receiver also sets the arena for what relationship is developed between the receiver and the suppliers.

Proposition 1: The initiation, development and termination of supplier relationships during a production transfer are dependent on the development of the focal relationship between sender and receiver.

This suggests that in order to improve production transfers, companies should direct their attention to developing their relationship with the receiving unit since this will indirectly also improve other involved relationships in the production transfer.

According to Håkansson and Snehota (1995) the atmosphere of a given relationship also dictates its quality. We can in the studied cases see that this is also true in relation to a production transfer. Especially how the actors view each other when the production transfer begins in relation to power and the intended goal of the relationship seem to impact on the relationship quality. In both the Sweden-Hungary transfer and the Sweden-China transfer, the sender was a relatively small customer of the receiver. Here company size and relationship atmosphere influences how prioritised the sender is and whether the sender trusts that the receiver will prioritise the sender. In addition to this perceived power there is also the actual power in the process, which stems from the actor who is managing the transfer. The actor who is managing the process can also interfere with the progress of the process in a more direct way. In the Sweden-Hungary case the receiver did not have the power to affect the transfer and thus took action to interfere with the transfer by voicing its concern regarding quality of equipment and drawings sent to them. The intended goal of the relationship refers to whether the actors intend the relationship to become a well-developed relationship or if they will be content with a more arms-length relationship and whether the two actors share the same view on this issue. In contrast, the dependence and power shift gradually between actors, and they are also influenced by changes in social distances (Ford, 1980) and the development of trust between the actors. We can see that in the cases were the receiver and sender share the same view (Sweden-Romania and Sweden-China) the development of trust is not inflicting with the progress of the transfer. As the example of the Sweden-Romania case showed, the receiver can gradually develop the necessary skills to take over the responsibility. However, in the Sweden-Hungarian case the sender and receiver do not share the same view of the intended goal of the relationship and it leads to delays in the progress of the transfer. Thus we can see that the focal relationship is impacted by the differences in power and size between sender and receiver as well as social and technological distances.

Proposition 2: To have a shared view between sender and receiver of the goal stage of the relationship will improve the transfer progress.

Previous studies such as Corsaro and Snehota (2011) argue that joint goals lead to increased collaboration in relationships. However, those studies refer to goals in general in the joint business. In the present study we only focus on a sub-set of these goals. Since this paper explores relationship development in production transfer we refer to goals in terms of which stage of development the sender and receiver intend the relationship to develop to. 
Proposition 2 suggests that in order to improve production transfers, companies should make sure to align their goals of the relationship with the receiving units goals early in the relationship development, so that the two units agree on what intended roles they are developing towards.

The central relationship development in all cases is the relationship between the sending and receiving unit. The more developed this relationship is in terms of trust and decreased social distance, the smoother the production transfer progresses. Actions and episodes with negative impact on this relationship will cause problems in the production transfer progress that will, in turn, cause even more negative developments in the relationship between the sending and receiving factory. The present paper has thereby confirmed the studies that argue that the production transfer progress influences the relationship (e.g. McIvor, 2000, Franceschini et al., 2003, Greaver, 1999, Schniederjans and Zuckweiler, 2004) as well as the studies that argue that the relationship may be influencing the production transfer progress (Nordigården, 2007; Rehme et al., 2013; Fredriksson et al., 2014). However, the present study identifies that it may be an interaction between the production transfer progress and the relationship, where there is a two-directed impact between the production transfer progress and the development of the focal relationship between sender and receiver. This is a contribution to both streams of literature.

Proposition 3: The development of the relationship between sender and receiver into further states will have a positive impact on the production transfer progress and the production transfer progress will have a positive impact on the development between sender and receiver.

This suggests that in order to improve production transfers, investments in improving the relationship between sender and receiver may be worthwhile since it may ignite a positive spiral.

As expected at the partnerbase level the third actors differed between captive offshoring and offshore outsourcing cases. According to Aarikka-Stenroos and Halinen's (2007) definition, the headquarter is a third party in the relationship initiation, so it can act both as a converter and an inhibitor. In the early stages of the relationship, it acted as a converter, because it initiated the transfer and thereby mediated the contact between the actors and more or less forced them to interact. Further, headquarter may initiate relationships with very large social distances, relationships that might not even have been initiated if the senders and receivers had chosen their own relations. However, the headquarter can also become an inhibitor to the relationship development if it tries to manage the developments in the relationship too heavily, thus causing them to linger. Similarly, the customers may act as both converters and inhibitors depending on their attitude toward the transfer seen in both the Sweden-Romania case as well as the Sweden-China case. Therefore third actors in the form of headquarters and customers can act as both converters and inhibitors of the focal relationship between sender and receiver develop and the transfer progress.

Proposition 4: When captive offshoring, if headquarters do not let sender and receiver act as independent companies there is a risk they move from being convertors to become inhibitors of the relationship development and the transfer progress.

This suggests that in order to improve production transfers, headquarters should be aware of the relationship dimension of production transfer, and more importantly, that relationships consist of trust and mutual experience that develop through interaction and not managerial decisions. 
Figure 3 below summarizes the cross-case findings in connection to the Figure 1 presented in the theoretical framework.

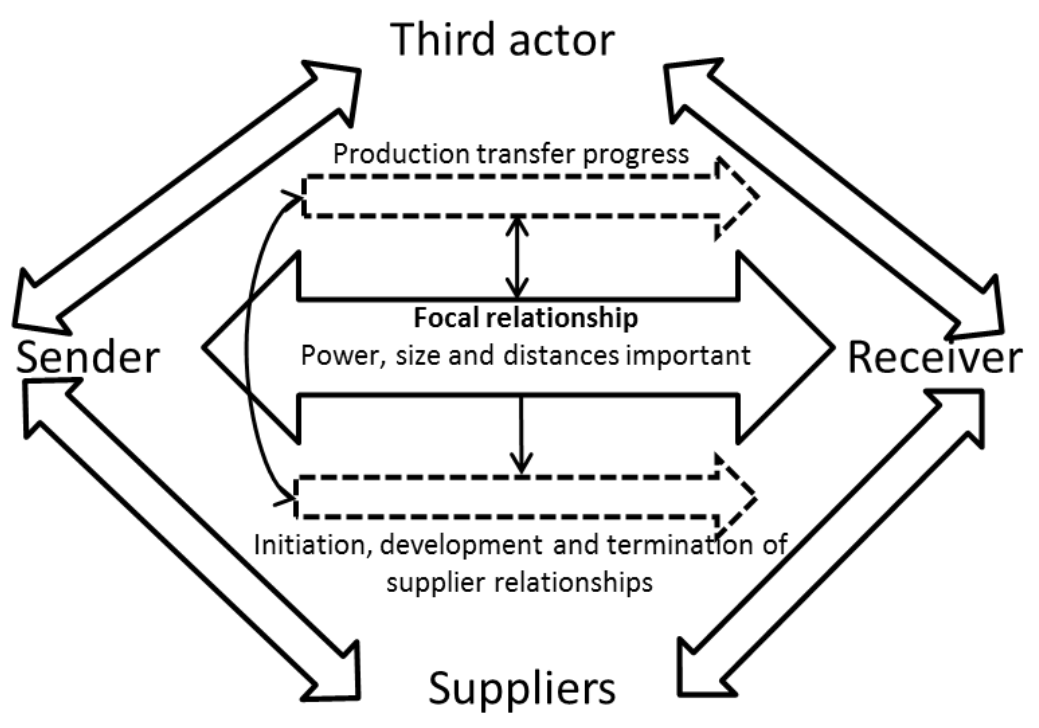

Figure 3: How relationship developments influence production transfer progress.

\section{Discussion and Conclusion}

The present paper provides an overview of three production transfers from the Swedish senders' perspective. By analysing the production transfers through the lens of relationship dynamics literature, we can see how the relationship development between sender and receiver impact production transfers. Based on the cross-case analysis, four propositions for further research are provided and these need to be tested through survey based studies. We also referenced factors from relationship dynamics literature to show the complexity of the outsourcing/offshoring situation as well as to point out the possibilities to improve its management. Below we discuss the findings in relation to the research questions presented last in the theoretical framework in order to elaborate on the contribution of the paper.

-How is the relationship between the sender and receiver related to the production transfer progress?

It is clear from the four transfers that the relationship between the sender and receiver is not a relationship that goes straight from zero to one, as depicted by the outsourcing literature (e.g., Kamann and van Nieulande, 2010; Trent and Monzcka, 2003). We contribute to the outsourcing literature by showing that the dependence and power shifts gradually between actors as the production transfer progresses, and this progress is highly dependent on previous interactions, i.e. the social distance at the start of the transfer. The finding of the importance of the social distance for developing the focal relationship between the sender and receiver, that in turn is interrelated with production transfer progress, supports the theoretical contribution of Ford (1980). Ford (1980, p. 345) explains that distances are reduced during relationship development and in the development stage of a relationship the social distance "is reduced by the social exchange which takes place between the companies" and that "The reduction in social distance also contributes to a lessening of the effects of geographical and cultural distance". However, the reverse situation where the social distance in the relationship 
is becoming larger due to problems in the production transfer is instead providing some support to proponents of relationship development models where the relationship can also develop into a less developed state (e.g. Batonda and Perry, 2003) even though these proponents tend to give less detailed descriptions of distances. This finding of the importance of the social distance in the relationship between the sender and receiver contributes to the outsourcing literature by showing that short social distance also assists production transfers, especially as the outsourcing literature tends to emphasise cultural distances as one of the most important obstacles (e.g. Fredriksson and Jonsson, 2009). In contrast to these previous assumptions in the outsourcing literature, it is not only the culture per se that should be taken into consideration when deciding where to move production but the current social distance between the sender and the potential receiver in that culture. A contribution can also be made in relation to the discussion of Mudambi and Venzin (2010) regarding of the relation between location and control decision. Based on above discussion it can be seen that a previously known location, i.e. short social distance, may improve the transfer progress and can be used as an argument to why location should be decided upon before control.

\section{- How do the relationship between the sender and receiver develop?}

The gradually developing relationship between the sender and receiver sets the arena for the relationships that between the receiver and the suppliers. In the relationship development process between sender and receiver, one of the most important milestones seems to be the point when the receiver stops being treated as a sub-supplier and becomes an independent supplier. Thus an interesting contribution to the outsourcing literature is that this finding shows it to be more important for the receiver than the sender to reach a more developed state of the relationship. It is also important for parties to have the same goal state of the relationship as well as a shared awareness of what state the relationship is in. Previous outsourcing literature has neglected the feelings of the receiver and mainly focused on how the sender view the progress (e.g. Mudambi and Venzin, 2010; Fredriksson et al., 2014). However, we can see here that there should be a match between the present state of the relationship between the sender to the receiver and the level of responsibility transferred; otherwise, there is a risk of conflicts. We can also see that the relational size and power of sender and receiver have an impact on how the relationship develops.

\section{-How is the relationship between the sender and receiver related to third actors?}

We can see that during captive offshoring the headquarters' involvement in our cases worked as both an inhibitor and a converter, confirming the survey-based research by Björkman et al. (2004) and Lyles and Salk (1996). The outsourcing literature (e.g., Greaver, 1999; Schniederjans and Zuckweiler, 2004) takes for granted that top management involvement can help the parties to execute decisions. However, we show here that this may hold true for offshore outsourcing but not for captive offshoring. Thus we contribute to the discussion brought up by Jahns et al. (2006) on the importance of clearly separating between studies of captive offshoring and offshore outsourcing. What we see is that if the sender and receiver feel too controlled and are not allowed to make their own decisions in captive offshoring, top management involvement can slow down the progress of the production transfer. We can also see that the customers can work as an inhibitor to the transfer through their self interest in how the transfer will impact quality.

All four propositions and Figure 3 point in the same direction. The development of the focal relationship between the sending unit and the receiving unit is the key to the production transfer. It impacts the production transfer progress as well as the other relationships involved in the system. The propositions also points to the vulnerability of this focal relationship. In 
order for the relationship to ignite a positive spiral there has to be a shared goal and the relationship has to be allowed to develop on its own. Consequently, the managerial implication of these propositions is that companies involved in production transfer should also focus on the focal relationship between sender and receiver. This may include change of plans in order to adapt the transfer activities to the current state of the relationship.

The contribution of this paper lies in the identification of relationship development between sender and receiver as a crucial factor in production transfers. Relationship development is beyond the interdependency between the two units, governance of the relationship and strategic questions of the relationship that have been previously discussed in outsourcing/offshoring literature (Wasner, 1999; Boulaksil and Fransoo, 2010; Fredriksson et al., 2014; McIvor, 2000; Franceschini et al., 2003; Greaver, 1999; Schniederjans and Zuckweiler, 2004; Baraldi et al., 2014; Kamann and van Nieulande, 2010; Trent and Monczka, 2003) since it consists of elements that cannot be completely controlled neither by managerial decisions nor the involved actors. This contribution opens up to future studies on facilitation of relationship development between senders and receivers in relation to outsourcing and offshoring decisions.

\section{References}

Aarikka-Stenroos, L. (2008) What really happens in initiation? - Investigating the subprocesses and features of emerging buyer-seller relationships, IMP Conference, Uppsala.

Aarikka-Stenroos, L. and Halinen, A. (2007) The promoting role of third actors in initiating relationships, IMP Conference, Manchester.

Alajoutsijärvi, K., Möller, K. and Tähtinen, J. (2000) Beautiful exit. How to leave your business partner, European Journal of Marketing, Vol. 34, No. 11/12, pp. 1270-1290.

Anderson, H., Havila, V. and Salmi, A. (2001) Can You Buy a Business Relationship? On The Importance of Customer and Supplier Relationships in Acquisitions, Industrial Marketing Management, Vol. 30, pp. 575-586.

Argote, L., McEvily, B. \& Reagans, R. (2003), "Managing Knowledge in Organizations: An Integrative Framework and Review of Emerging Themes", Management Science, Vol. 49, No. 4, pp. 571-582.

Arlbjørn, J.S. and Mikkelsen, O.S. (2014) Backshoring manufacturing: Notes on an important but under-researched theme, Journal of Purchasing \& Supply Management, Vol. 20, pp. 6062.

Baptista, C. 2013. Interaction processes in long-term relationships in the metal mining industry: Longitudinal case studies of capital equipment buying, Industrial Marketing Management, Vol. 42, pp. 969-982.

Baraldi, E., Proenca, J.F., Proenca, T. and Mota de Castro, L. (2014) The supplier's side of outsourcing: Taking over activities and blurring organizational boundaries, Industrial Marketing Management, Vol. 43, pp. 553-563. 
Batonda, G. and Perry, C. (2003) Approaches to relationship development processes in interfirm networks, European Journal of Marketing, Vol. 37, No. 10, pp. 1457-1484.

Barratt, M., Choi, T. Y. and Li, M. (2011) Qualitative case studies in operations management: trends, research outcomes, and future research implications, Journal of Operations Management, Vol. 29, No. 4, pp. 329-342.

Biggemann, S. (2012) The essential role of information sharing in relationship development, Journal of Business \& Industrial Marketing, Vol. 27, No. 7, pp. 521-526.

Björkman, I., Barner-Rasmussen, W. and Li, L. (2004) Managing Knowledge Transfer in MNCs: The Impact of Headquarters Control Mechanisms. Journal of International Business Studies, Vol. 35, No. 5, pp. 443-455

Boulaksil, Y. and Fransoo, J. C. (2010) Implications of outsourcing on operations planning: findings from the pharmaceutical industry. International Journal of Operations and Production Management, 30, pp. 1059-1079.

Cheng, Y., Madsen, E. S. and Liangsiri, J. (2010) Transferring knowledge in the relocation of manufacturing units, Strategic Outsourcing: An International Journal Vol. 3, No. 1, pp. 519.

Corsaro, D. and Snehota, I. (2011) Alignment and Misalignment in Business Relationships, Industrial Marketing Management, Vol. 40, pp. 1042-1054.

Edvardsson, B., Holmlund, M. and Strandvik, T. (2008) Initiation of business relationships in service-dominant settings. Industrial Marketing Management, Vol. 37: pp. 339-350.

Eisenhardt, K.M. (1989) Building theories from case study research. The Academy of Management Review, Vol. 14, pp. 532-550.

Eltantawy, R.A. and Giunipero, L. (2013) An empirical examination of strategic sourcing dominant logic: Strategic sourcing centricity. Journal of Purchasing \& Supply Management, Vol. 19, pp. 215-226.

Flick, U. (2015) Introducing Research Methodology. $2^{\text {nd }}$ Ed. SAGE Publications, London.

Ford, D. (1984) Buyer/Seller Relationships in International Industrial Markets, Industrial Marketing Management, Vol. 13, pp. 101-112.

Ford, D. (1980) The Development of Buyer-Seller Relationships in Industrial Markets, European Journal of Marketing, Vol. 14, No. 5/6, pp. 339-354.

Fratocchi, L., Di Mauro, C., Barbieri, P. and Nassimbeni, G. (2014) When manufacturing moves back : Concepts and questions. Journal of Purchasing \& Supply Management, Vol. 20, pp. 54-59.

Franceschini, F., Galetto, M., Pignatelli, A. \& Varetto, M. (2003), "Outsourcing: guidelines for a structured approach", Benchmarking: An international Journal, Vol. 10, No. 3, pp. 246260. 
Fredriksson, A. (2011), Materials supply and production outsourcing, $\mathrm{PhD}$, Chalmers University of Technology.

Fredriksson, A. and Jonsson, P. (2009) Assessing consequences of low cost sourcing in China. International Journal of Physical Distribution and Logistics Management, Vol. 39, No. 3, pp. 227-249.

Fredriksson, A., Wänström, C. and Medbo, L. (2014) Assuring materials availability during the production transfer process - Critical characteristics of the materials planning environment. Journal of Manufacturing Technology Management, Vol.25, No. 6.

Fredriksson, A. and Wänström, C. (2014) Manufacturing and supply chain flexibility towards a tool to analyse production network coordination at an operational level. Strategic Outsourcing: An International Journal, Vol 7, No. 2, pp. 173-194.

Greaver, M. F. (1999), Strategic Outsourcing - A structured approach to outsourcing decisions and initiatives, AMACOM, New York.

Halvorsen, K. (1992) Samhällsvetenskaplig metod, Lund, Studentlitteratur.

Harrison, D., Holmen, E. and Pedersen, A.-C. (2012) When everyone is connected to everyone: exploring role dynamics in triads, Proceedings of the $28^{\text {th }}$ annual IMP conference, Rome, Italy.

Havila, V. and Medlin, C.J. (2012) Ending-competence in business closure, Industrial Marketing Management, Vol. 41, No. 3, pp. 413-420.

Havila, V. and Wilkinson, I.F. (2002) The principle of the conservation of business relationship energy: or many kinds of new beginnings, Industrial Marketing Management, Vol. 31, pp. 191-203.

Holmen, E., Roos, K., Kallevåg, M., von Raesfeld, A., de Boer, L., and Pedersen, A.-C. (2005) How do relationships begin?, $21^{\text {st }}$ IMP Conference, Rotterdam.

Holmlund, M. (2004) Analyzing business relationships and distinguishing different interaction levels, Industrial Marketing Management, Vol. 33, pp. 279-287.

Horn, P., Schiele, H. and Werner, W. (2013) The "ugly twins": Failed low-wage-country sourcing projects and their expensive replacements, Journal of Purchasing \& Supply Management, Vol. 19, pp. 27-38.

Håkansson, H. and Ford, D. (2002) How should companies interact in business networks?, Journal of Business Research, Vol. 55, pp. 133-139.

Håkansson, H. and Snehota, I. (1995) Developing Relationships in Business Networks. London: Routledge.

Jahns, C., Hartmann, E., and Bals, L. (2006) Offshoring: Dimensions and diffusion of a new business concept, Journal of Purchasing \& Supply Management, Vol. 12, pp. 218-231. 
Jensen, P.D.Ö, Larsen, M.M., and Pedersen, T. (2013) The organizational design of offshoring: Taking stock and moving forward, Journal of International Management, Vol. 19, pp. 315-323.

Jensen, R.J. and Szulanski, G. (2004) Stickiness and the adaptation of organizational practices in cross-border knowledge transfers, Journal of International Business Studies, Vol. 35, No. 6, pp. 508-523.

Jonsson, A. and Foss, N.J. (2011) International expansion through flexible replication: Learning from the internationalization experience of IKEA, Journal of International Business Studies, Vol. 42, No. 9, pp. 1079-1102.

Mitrega, M., Forkman, S., Ramos, C. and Henneberg, S.C. (2012) Networking capability in business relationships - Concept and scale development, Industrial Marketing Management, Vol. 41, pp. 739-751.

Mitrega, M. and Zolkievski, J. (2012) Negative consequences of deep relationships with suppliers: An exploratory study in Poland, Industrial Marketing Management, Vol. 41, pp. 886-894.

Mudambi, R. and Venzin, M. (2010) The strategic nexus of offshoring and outsourcing decisions, Journal of Management Studies, Vol. 47, No. 8, pp. 1510-1533.

Kamann, D.J. and van Nieulande, V. (2010) A four-filter method for outsourcing to low-cost countries, Journal of Supply Chain Management, Vol. 46, No. 2, pp. 64-79.

Kinkel, S. (2014) Future and impact of backshoring - Some conclusions from 15 years of research on German practices, Journal of Purchasing \& Supply Management, Vol. 20, pp. 63-65.

Leek, S. and Canning, L. (2011) Entering and developing a service network, Journal of Services Marketing, Vol. 25, No. 1, pp. 58-67.

Leek, S. and Mason, K. (2010) The utilization of network pictures to examine a company's employees' perceptions of supplier relationship, Industrial Marketing Management, Vol. 39, pp. 400-412.

Lyles, M., A. and Salk, J. E. (1996) Knowledge Acquisition from Foreign Parents in International Joint Ventures: An Empirical Examination in the Hungarian Context. Journal of International Business Studies, Vol. 27, No. 5, pp. 877-903.

Madsen, E. S. (2009), Knowledge transfer in global production, PhD, Aalborg University.

Martin, X., Mitchell, W. and Swaminathan, A. (1995) Recreating and extending Japanese automobile buyer-supplier links in North America. Strategic Management Journal, Vol. 16, pp. 589-619. 
McBeath, A. \& Ball, P. (2012), Towards a framework for transferring technology knowledge between facilities, Strategic Outsourcing: An International Journal, Vol. 5, No. 3, pp. 213231.

McIvor, R. T. (2000), A practical framework for understanding the outsourcing process, Supply Chain Management: An international journal, Vol. 5, No. 1, pp. 22-36.

Munksgaard, K.B., Johnsen, R.E. and Patterson, C.M. (2015), Knowing me, knowing you: Self- and collective interests in goal development is asymmetric relationships, Industrial Marketing Management, Vol. 48, pp. 160-173.

Najafi, N., Dubois, A. and Hulthén, K. (2013) Opportunism or strategic opportunity seeking? Three approaches to emerging country sourcing. Journal of Purchasing \& Supply Management, Vol. 19, pp. 49-57.

Nordigården, D. 2007. Outsourcing in the Wood Product Manufacturing Sector - A Combined Customer and Supplier Perspective. PhD, Linköping University.

Polonsky, M., Gupta, S., Beldona, S. and Hyman, M.R. (2010) Inactivity and the dynamics of relationship development: a proposed model, Journal of Strategic Marketing, Vol. 18, No. 3, pp. 257-273.

Rehme, J., Nordigården, D., Brege, S. and Chicksand, D. (2013) Outsourcing to a nondeveloped supplier market: The importance of operational aspects in outsourcing, Journal of Purchasing and Supply Management, Vol. 19, No. 4, pp. 227-237.

Ritter, T., Wilkinson, I.F. and Johnston, W.J. (2004) Managing in complex business networks, Industrial Marketing Management, Vol. 33, pp. 175-183.

Rivkin, J.W. (2001) Reproducing knowledge: Replication without imitation at moderate complexity, Organization Science, Vol. 12, No. 3, pp. 274-293.

Ryan, A., Tähtinen, J., Vanharanta, M. and T. Mainela. (2012) Putting critical realism to work in the study of business relationship processes, Industrial Marketing Management, Vol. 41 , pp. 300-311.

Salo, A., Tähtinen, J. and Ulkuniemi, P. (2009) Twists and turns of triadic business relationship recovery, Industrial Marketing Management, Vol. 38, pp. 618-632.

Salomon, R. and Martin, X. (2008), Learning, Knowledge Transfer, and Technology Implementation Performance: A study of Time-to-Build in the Global Semiconductor Industry, Management Science, Vol. 54, No. 7, pp. 1266-1280.

Schniederjans, M. J., Schniederjans, A. M. and Schniederjans, D. G. (2005), Outsourcing and insourcing in an international context, M.E. Sharpe Inc., New York.

Schniederjans, M. J. and Zuckweiler, K. M. (2004), A quantitative approach to the outsourcing-insourcing decision in an international context, Management Decision, Vol. 42, No. 8, pp. 974-986. 
Slotte-Kock, S. and Coviello, N. (2009), Entrepreneurship Research on Network Processes: A Review and Ways Forward, Entrepreneurship Theory and Practice, Vol. 34, No. 1, pp. 3157.

Strömsten, T. and Waluszewski, A. (2012) Governance and resource interaction in networks. The role of venture capital in a biotech start-up, Journal of Business Research, Vol. 65, pp. 232-244.

Tate, W.L. (2014) Offshoring and reshoring: U.S. insights and research challenges, Journal of Purchasing \& Supply Management, Vol. 20, pp. 66-68.

Trent, R. and Monczka, R. (2003) Understanding integrated global sourcing. International Journal of Physical Distribution and Logistics Management, Vol. 33, No. 7, pp. 607-629.

Tähtinen, J., Paparoidamis, N.G., and Chumpitaz, R. (2007) Business Relationship Recovery - A Process Model, $23^{\text {rd }}$ annual IMP conference, Manchester, UK.

Tähtinen, J. and Vaaland, T.I. (2006) Business relationships facing the end: why restore them?, The Journal of Business \& Industrial Marketing, Vol. 21, No. 1, pp. 14-23.

Vaaland, T.I. and Håkansson, H. 2003. Exploring interorganizational conflict in complex projects, Industrial Marketing Management, Vol. 32, pp. 127-138.

Voss, C., Tsikriktsis, N. and Frohlich, M. 2002. Case research in operations management. International Journal of Operations \& Production Management, Vol. 22, pp. 195-219

Wasner, R. 1999. The process of outsourcing - strategic and operational realities. Ekonomie Licentiat, Linköping University.

Yin, R. K. (2003) Case Study Research: Design and Methods, Thousand Oaks, SAGE Publications. 